\title{
IMPLEMENTASI TEKNOLOGI REALITAS AUGMENTASI SEBAGAI MEDIA PEMBELAJARAN PENGENALAN HEWAN PADA PAUD
}

\author{
Khairul Imam ${ }^{1^{*}}$, Verdi Yasin ${ }^{2}$, Anton Zulkarnain Sianipar ${ }^{3}$ \\ ${ }^{1,2,3}$ Teknik Informatika, STMIK Jayakarta, \\ Jalan. Salemba I No.10, RT.4/RW.6, Kenari, Kec. Senen, Jakarta Pusat 10430 Indonesia \\ *e-mail:khairulimam08@gmail.com,verdiyasin29@gmail.com. antonz.jayakarta@gmail.com \\ 17570046@stmik.jayakarta.ac.id,verdi_yasin@stmik.jayakarta.ac.id,antonz@stmik.jayakarta.ac.id
}

Received: July 25, 2021, Revised: August 16, 2021 Accepted: August 25, 2021

\begin{abstract}
Abstrak
Paud Tunas Harapan Bangsa merupakan tempat anak-anak usia dini yang menempuh jenjang pendidikan sebelum masuk ke sekolah dasar. Pada masa pandemi ini perkembangan teknologi sangat di butuhkan untuk menunjang kegiatan belajar mengajar, Termasuk Tunas Harapan Bangsa. Kendala yang di hadapi dalam pembelajaran adalah kurangnya metode belajar yang informatif dan interaktif. Maka dari itu peneliti ingin membuat aplikasi berbasis realitas augmentasi dengan metode pengembangan model waterfall dan metode metode perancangan menggunakan unity dah vuforia. Tujuan penelitian ini adalah untuk menunjang kegiatan belajar yang lebih praktis, informatif dan inovatif.

Kata kunci: Paud Tunas Harapan, Realitas Augmentasi, Unity dan Vuforia.

Abstract

Tunas Harapan Bangsa Paud is a place for early childhood children to take education before entering elementary school. During this pandemic, technological developments are urgently needed to support teaching and learning activities, including Tunas Harapan Bangsa. The obstacle faced in learning is the lack of informative and interactive learning methods. Therefore, the researcher wants to create an augmented reality-based application with the waterfall model development method and the design method using unity and vuforia. The purpose of this research is to support learning activities that are more practical, informative and innovative
\end{abstract}

Keywords: Paud Tunas Harapan Bangsa, Augmented Reality, Unity and Vuforia

\section{Pendahuluan (Introduction)}

Paud Tunas Harapan Bangsa merupakan salah satu PAUD yang ada di kota Jakarta Timur. Pada masa pandemic ini PAUD Tunas Harapan Bangsa melakukan kegiatan belajar mengajar dengan menggunakan sistem daring. Salah satu alat penunjang kegiatan belajar mengajar menggunakan sistem daring adalah smartphone. Salah satu OS (Sistem Operasi) pada smartphone yang sedang berkembang pesat adalah Android. Menurut hasil survey yang dilakukan oleh Nielsen (2015), smartphone berbasis android telah mempunyai pengguna terbanyak di banding yang lain. Diiringi dengan pesatnya perkembangan smartphone android, Munculah Realitas Augmentasi yang biasa disebut dengan AR. Realitas Augmentasi adalah suatu lingkungan yang memasukkan objek virtual 3D kedalam lingkungan nyata. Karena itu, unsur realitas lebih di utamakan pada system ini. AR memungkinkan pengguna nya untuk berinteraksi secara real time dengan sistem. Masyarakat umum 
masih belum begitu mengenal apa itu augmented reality, menurut Wikipedia Realitas Augmentasi merupakan teknologi yang menggabungkan benda maya 2 dimensi dan ataupun 3 dimensi ke dalam sebuah lingkungan nyata lalu memproyeksikan benda - benda maya tersebut dalam waktu nyata. Pada proses pengenalan hewan pada anak usia dini salah satu nya, Tentunya dibutuhkan suatu pengamatan terhadap hewan-hewan seperti gajah, kucing, anjing, dan lain-lain. Pada PAUD Tunas Harapan Bangsa tentunya aplikasi yang ingin di buat juga mempermudah guru dan orangtua dalam mengenalkan berbagai makhluk hidup yang ada di sekitar lingkungan mereka. Pengenalan hewan kepada anak juga dapat merangsang otak untuk berimajinasi dan melatih kreatifitas. Metode yang dilakukan dalam pembuatan aplikasi Pengenalan Hewan ini adalah study literatur, eksperimen, sampling dan interview. Pembuatan diawali dengan mengumpulkan data hewan yang akan di buat sebagai model. Perancangan aplikasi Realitas Augmentasi menggunakan software Vuforia dengan merancang marker yang di buat dan model hewan yang telah dibuat dengan unity.

\section{Tinjauan Literatur (Literature Review)}

Penelitian yang berjudul "Implementasi Augmented Reality (AR) pada Pengembangan Media pembelajaran Permodelan Bangun Ruang 3D untuk Siswa Sekolah Dasar" oleh Enang Rusnandi, Harun Sujadi dan Eva Fibriyany Noer Fauzyah (2016). Berawal dari masalah bahwa pemodelan matematika pada materi bangun ruang yang saat ini masih disampaikan secara manual. Maka penelitian ini akan mencoba membuat solusi masalah tersebut dengan mengembangkan media pembelajaran dengan menggunakan teknologi augmented reality (AR), yaitu teknologi yang menggabungkan objek virtual dua dimensi atau tiga dimensi ke dalam sebuah lingkungan nyata dan kemudian memproyeksikan objek maya tersebut secara realtime. Pada media ini pula dijelaskan materi pembelajaran berupa, nama bangun dan rumusrumusnya. Dengan menggunakan aplikasi ini diharapkan siswa menjadi lebih tertarik mempelajari matematika khususnya pada materi bangun ruang.

Penelitian berjudul "Pengembangan Teknologi Augmented Reality Sebagai Penguatan dan Penunjang Metode Pembalajaran di SMK umtuk Implementasi Kurikulum 2013" oleh Mantasia dan Hendra Jaya (2016). Kesimpulan yang diperoleh dalam penelitian ini adalah sebagai berikut. Pertama, tahap pengembangan Augmented Reality terbagi ke dalam tahapan kecil yaitu pembuatan antarmuka multimedia, coding atau pengkodean, movie testing, publishing, packaging, validasi ahli dan revisi multimedia. Untuk mengintegrasikan Augmented Reality dengan Kurikulum 2013, maka dalam penelitian ini dibuat modul yang berkaitan dengan kaidahkaidah yang ada dalam pembelajaran saintifik (scientific learning).

\section{Metode Penelitian (Research Method)}

\subsection{Metode Pengumpulan Data}

berikut:

Dalam penelitian ini cra mengumpulkan data dilakukan dengan metode antara lain sebagai

\section{a. Metode Observasi}

Untuk melengkapi data yang diperoleh, maka dilakukan pengamatan dan penelitian serta menganalisa semua data yang diperoleh untuk mengetahui dan melihat secara langsung proses pengelolaan kegiatan tersebut sehingga penulis dapat menganalisa permasalahan dan membuat solusi atas permasalahan yang terjadi saat ini. Observasi dilakukan di PAUD Tunas Harapan Bangsa.

b. Metode Wawancara

Dilakukan untuk mendapat informasi yang dibutuhkan untuk pembuatan sistem berupa kegiatan tanya jawab terhadap pimpinan dan guru di PAUD tunas harapan bangsa mengenai 
sistem yang sedang berjalan. Wawancara dilakukan dengan Ibu Siti Nurhayati selaku pimpinan di PAUD Tunas Harapan Bangsa, Adapun hasil wawancara menjelaskan bahwa metode pembelajaran kurang informatif dan inovatif sehingga kurang nya minat belajar dari para siswa

c. Studi Pustaka

Studi pustaka yang dilakukan penulis berupa pengumpulan data dengan cara mencari buku-buku referensi, tutorial atau bahan-bahan teori yang diperlukan dari berbagai sumber yang berkaitan dengan pembuatan tugas akhir.

\subsection{Metode Analisis}

a. Analisis SWOT

Analisa ini didasarkan pada hubungan antara unsur - unsur internal, yaitu kekuatan (strength) dan kelemahan (weakness), terhadap unsur - unsur eksternal yaitu peluang (opportunities) dan ancaman (treats).

\section{Tabel 3. 1 Analisis SWOT}

\begin{tabular}{|c|c|}
\hline S (Strength) & W (Weakness) \\
\hline $\begin{array}{l}\text { 1. Mudah dalam mengoperasikan } \\
\text { aplikasi pengenalan hewan } \\
\text { 2. Setiap guru mampu } \\
\text { mengoperasikan smartphone }\end{array}$ & $\begin{array}{l}\text { 1. Metode yang di ajarkan di } \\
\text { PAUD Tunas Harapan } \\
\text { Bangsa selalu berulang. } \\
\text { 2. Siswa kurang interaktif } \\
\text { dengan metode pembelajaran } \\
\text { yang ada }\end{array}$ \\
\hline O (Opportunity) & T (Threats) \\
\hline $\begin{array}{l}\text { 1. } \begin{array}{l}\text { Sistem aplikasi yang akan } \\
\text { dibangun berbasis realitas } \\
\text { augmentasi }\end{array} \\
\text { 2. Guru dapat membuat siswa } \\
\text { antusias dalam kegiatan belajar } \\
\text { mengajar }\end{array}$ & $\begin{array}{l}\text { 1. Sudut pandang pengguna harus } \\
\text { sesuai agar dapat menampilkan } \\
\text { animasi tiga dimensi di aplikasi } \\
\text { tersebut }\end{array}$ \\
\hline
\end{tabular}

b. Analisis Sistem dan Aplikasi

Dalam penelitian ini akan menghasilkan suatu aplikasi berbasis realitas augmentasi yang akan digunakan untuk metode pembelajaran baru di PAUD Tunas Harapan Bangsa diantaranya adalah sebagai berikut :

a. Aplikasi mampu memberikan pengalaman baru bagi guru maupun siswa di PAUD Tunas Harapan Bangsa.

b. Aplikasi dapat memberikan pengenalan hewan secara realtime kepada siswa PAUD Tunas Harapan bangsa

c. Analisis Hardware dan Software

Untuk membangun sebuah sistem yang baik dan juga memungkinkan, maka di butuhkan juga Perangkat Keras (Hardware) dan Perangkat Lunak (Software) yang memadai agar terciptanya sebuah program data kehadiran karyawan berbasis web yang sesuai dengan kebutuhan sebagai berikut.

a. Analisa Kebutuhan Perangkat Lunak(Software) 
Kebutuhan perangkat keras, pengembangan perangkat lunak atau hsoftware adalah seluruh komponen peralatan yang membentuk suatu sistem komputer dan peralatan lainnya yang memungkinkan komputer dapat melaksanakan tugas dan fungsinya

b. Analisa Kebutuhan Perangkat Keras (Hardware)

Kebutuhan perangkat keras, pengembangan perangkat keras atau hardware adalah seluruh komponen peralatan yang membentuk suatu sistem komputer dan peralatan lainnya yang memungkinkan komputer dapat melaksanakan tugas dan fungsinya.

\subsection{Metode Pengembangan}

Dalam model ini ada beberapa fase yang dapat dilihat pada Gambar Model Waterfall, model ini memiliki tahapan yang terdiri dari permulaan sistem, analisis sistem, perancangan sistem, dan implementasi sistem. Namun dalam penelitian ini penulisan hanya membahas tahap perancangan sistem, analisis sistem, dan implementasi sistem.

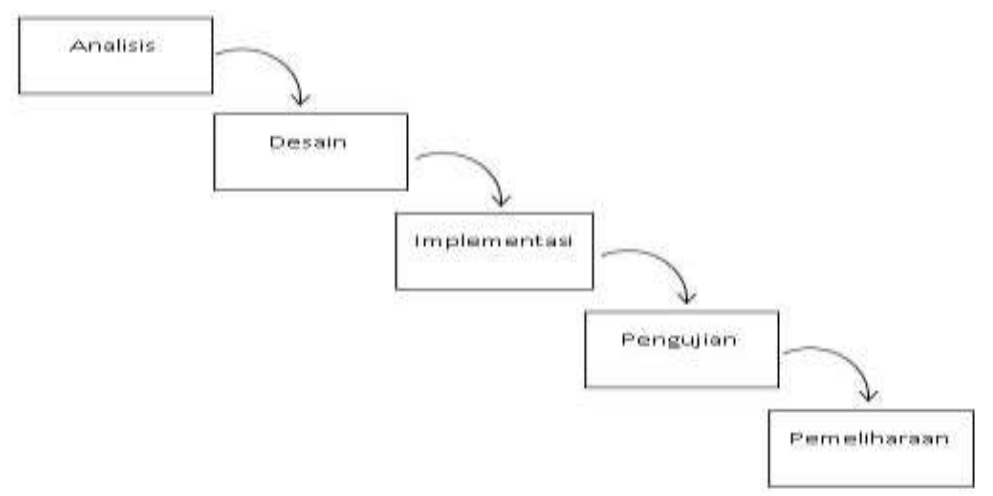

Gambar 3. 1 Model Waterfall

Berikut adalah tahapan yang dilakukan dengan menggunakan model waterfall :

1. Analisis Kebutuhan

Kebutuhan yang didapatkan dari hasil wawancara dengan Kepala Sekolah dan Guru di PAUD Tunas Harapan Bangsa dianalisa untuk mendapatkan kebutuhan aplikasi. Kebutuhan aplikasi ini kemudian dijadikan referensi untuk merancang aplikasi.

2. Desain

Tahap design digunakan untuk menerjemahkan kebutuhan perangkat lunak dari tahap analisis ke desain. Desain yang dibuat berupa sketsa desain aplikasi dengan menggunakan UML.

3. Implementasi

Setelah desain dibuat, tahap selanjutnya yaitu membuat atau mengembangkan aplikasi perangkat lunak yaitu aplikasi yang menggunakan teknologi Augmented Reality.

4. Pengujian

Pada tahap pengujian, verifikasi dan validasi aplikasi perangkat lunak dilakukan. Tahap pengujian digunakan untuk menemukan kesalahan atau debug pada saat pembuatan aplikasi.

5. Pemeliharaan

Tahap terakhir dari model waterfall ini adalah tahapan pemeliharaan. Proses instalasi produk dan pemeliharaan dilakukan dalam tahap pemeliharaan.. 


\subsection{Instrumen Penelitian}

Dalam penelitian ini penulis menggunakan penelitian Kualitatif, Metode penelitian yang digunakan adalah metode kualitatif. "Metodologi adalah proses, prinsip, dan prosedur yang kita gunakan untuk mendekati problem dan mencari jawaban" Menurut(Gamal Thabroni, 2021). Metode penelitian kualitatif adalah penelitian yang menggunakan cara, langkah, dan prosedur yang lebih melibatkan data dan informasi yang diperoleh melalui responden sebagai subjek yang dapat mencurahkan jawaban dan perasaannya sendiri untuk mendapatkan gambaran umum yang holistik mengenai suatu hal yang diteliti. Dalam penelian ini penulis perlu mengembangakan instrumen penelitian tersebut dan penulis mendapat tiga (3) instrumen penelitian yang dimana cara ini untuk melengkapi penelitian. Adapun instrumen sebagai berikut :

1. Sistem penerapan metode gambar

2. Sistem metode belajar

3. Sistem metode penilaian

\subsection{Metode Pengujian}

Dalam metode pengujian ini, peneliti akan menggunakan pengujian terhadap program yang dibuat menggunakan uat testing yang fokus terhadap proses masukan dan keluaran program yang meliputi :

a. Pengujian terhadap aplikasi yang dibuat

\section{Hasil dan Pembahasan (or Results and Analysis)}

\subsection{Lokasi Penelitian}

PAUD Tunas Harapan Bangsa didirikan pada tanggal 12 juni 2010 yang beralamat di Jatinegara Lio RT.009/ RW.04 No.1 Kelurahan Jatinegara, Kecamatan Cakung, Jakarta Timur. PAUD Tunas Harapan bangsa berintegrasi dengan PKK RW.04. PAUD Tunas Harapan Bangsa bergerak di bidang pendidikan anak usia dini, yang di bangun oleh masyarakat yang peduli dengan pendidikan di lingkungan daerah sekitar 
Volume 2, Nomor 2,Oktober 2021: halaman 102-114

https://jurnal.amikwidyaloka.ac.id/index.php/awl

jurnal@amikwidyaloka.ac.id / editor.jurnalwidya@gmail.com

\subsection{Flowmap Diagram}

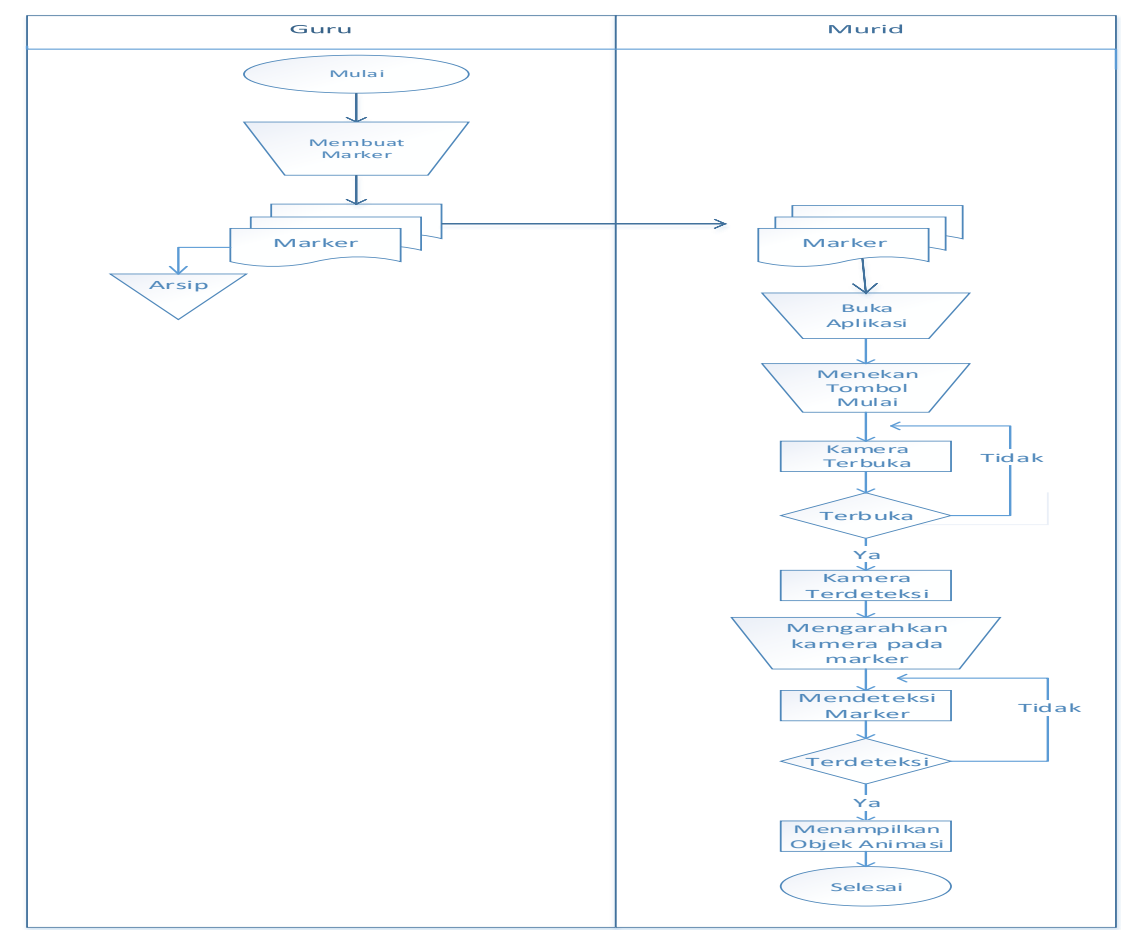

Gambar 4. 1 Flowmap Diagram

Tabel 4. 1 Keterangan Flowmap Diagram

\begin{tabular}{|c|l|}
\hline No & \multicolumn{1}{|c|}{ Keterangan } \\
\hline 1 & Mulai \\
\hline 2 & Guru membuat marker \\
\hline 3 & Marker siap dibagikan ke siswa \\
\hline 4 & Siswa menerima marker \\
\hline 5 & Siswa menekan tombol mulai pada aplikasi \\
\hline 6 & Siswa membuka aplikasi \\
\hline 7 & Kamera terbuka otomatis dari sistem \\
\hline 8 & Apabila kamera tidak terbuka, coba buka aplikasi kembali \\
\hline 9 & Kamera terdeteksi oleh sistem \\
\hline 10 & Siswa mengarahkan kamera pada marker \\
\hline 11 & Sistem mendeteksi marker \\
\hline 12 & $\begin{array}{l}\text { Apabila marker tidak terdeteksi, arahkan kembali kamera pada } \\
\text { marker }\end{array}$ \\
\hline 13 & Sistem menampilkan objek animasi \\
\hline 14 & Selesai \\
\hline
\end{tabular}


Volume 2, Nomor 2,Oktober 2021: halaman 102-114

https://jurnal.amikwidyaloka.ac.id/index.php/awl

jurnal@amikwidyaloka.ac.id / editor.jurnalwidya@gmail.com

\subsection{Use Case Diagram Sistem}

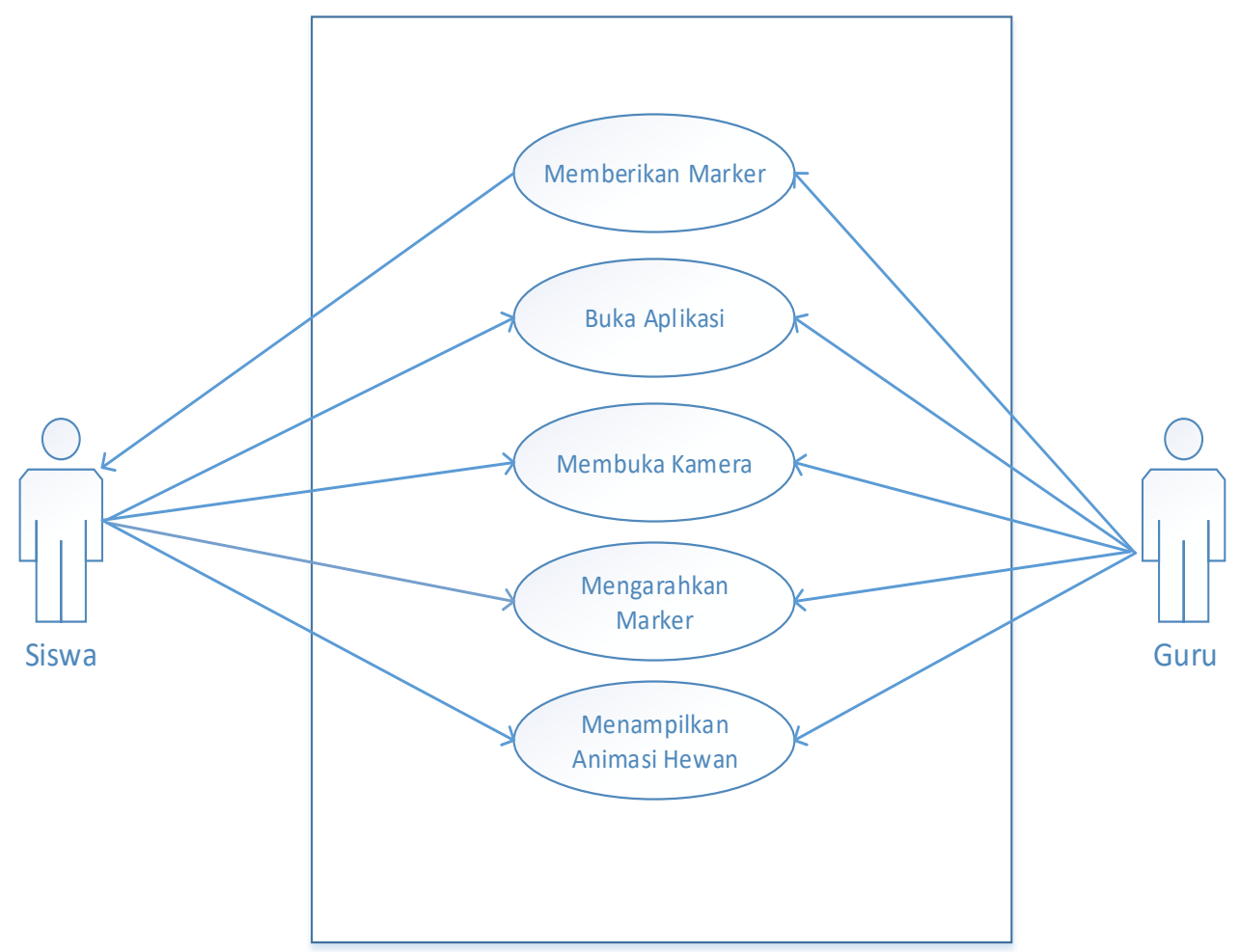

Gambar 4. 2 Use Case Diagram Sistem

Berdasarkan gambar 4.2 terlihat sebuah Use Case Diagram dari Sistem, Terdapat 2 aktor yaitu aktor Siswa dan Guru. Siswa melakukan kegiatan belajarnya menggunakan aplikasi pengenalan hewan yang dimana guru ikut serta mengawasi siswa dalam penggunaan aplikasi tersebut. 
Volume 2, Nomor 2,Oktober 2021: halaman 102-114

https://jurnal.amikwidyaloka.ac.id/index.php/awl

jurnal@amikwidyaloka.ac.id / editor.jurnalwidya@gmail.com

\subsection{Activity Diagram Siswa}

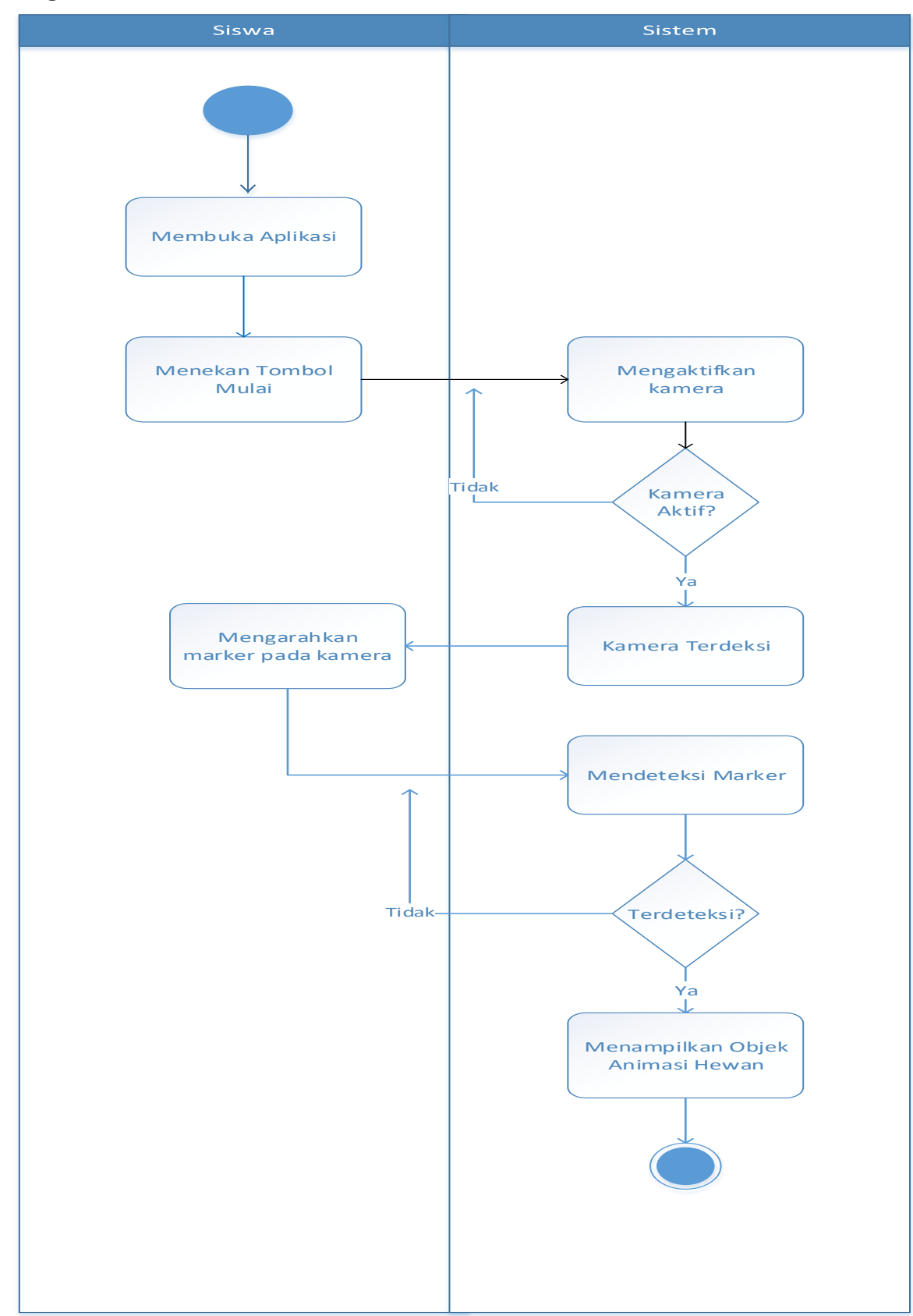

Gambar 4. 3 Activity Diagram Siswa

Tabel 4. 2 Keterangan Activity Diagram Siswa

\begin{tabular}{|c|l|}
\hline No & \multicolumn{1}{|c|}{ Keterangan } \\
\hline 1 & Mulai \\
\hline 2 & Siswa membuka aplikasi \\
\hline 3 & Siswa menekan tombol mulai pada aplikasi \\
\hline 4 & Kamera akan aktif otomatis dari sistem \\
\hline 5 & Apabila kamera tidak terbuka, coba buka aplikasi kembali \\
\hline
\end{tabular}


Volume 2, Nomor 2,Oktober 2021: halaman 102-114

https://jurnal.amikwidyaloka.ac.id/index.php/awl

jurnal@amikwidyaloka.ac.id / editor.jurnalwidya@gmail.com

\begin{tabular}{|c|l|}
\hline 6 & Kamera terdeteksi oleh sistem \\
\hline 7 & Siswa mengarahkan kamera pada marker \\
\hline 8 & Sistem mendeteksi marker \\
\hline 9 & $\begin{array}{l}\text { Apabila marker tidak terdeteksi, arahkan kembali kamera ke arah } \\
\text { marker }\end{array}$ \\
\hline 10 & Sistem menampilkan objek animasi hewan \\
\hline 11 & Selesai \\
\hline
\end{tabular}

\subsection{Activity Diagram Guru}

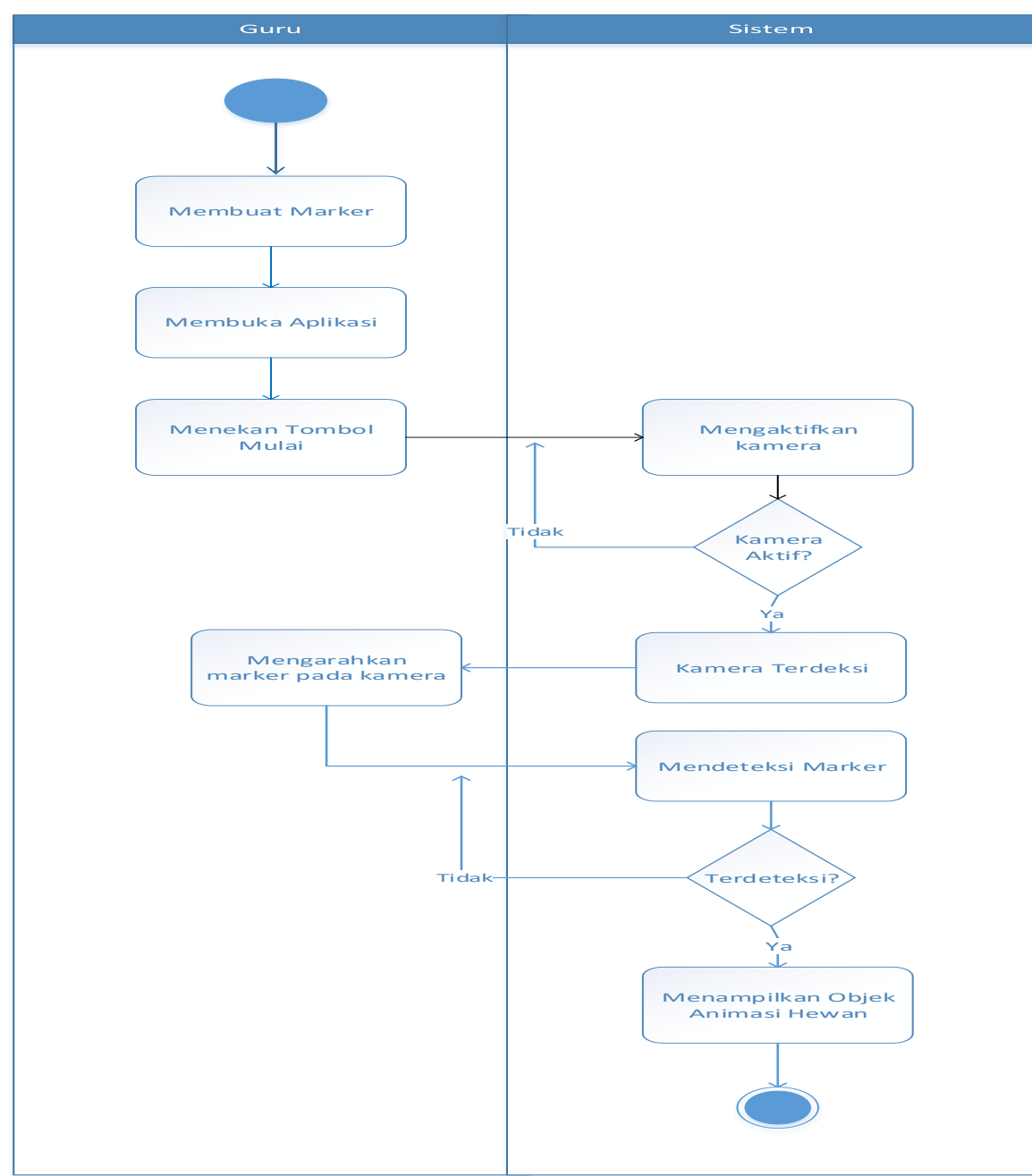

Gambar 4. 4 Activity Diagram Guru

Tabel 4. 3 Keterangan Activity Diagram Guru

\begin{tabular}{|c|l|}
\hline No & \multicolumn{1}{|c|}{ Keterangan } \\
\hline 1 & Mulai \\
\hline 2 & Membuat Marker \\
\hline 3 & Guru mengawasi siswa membuka aplikasi \\
\hline 4 & Guru mengawasi siswa dalam menekan tombol mulai \\
\hline 5 & Sistem mengaktifkan kamera \\
\hline 6 & Kamera akan aktif secara otomatis dari sistem \\
\hline
\end{tabular}


Volume 2, Nomor 2,Oktober 2021: halaman 102-114

https://jurnal.amikwidyaloka.ac.id/index.php/awl

jurnal@amikwidyaloka.ac.id / editor.jurnalwidya@gmail.com

\begin{tabular}{|c|l|}
\hline 7 & Apabila kamera tidak aktif, coba buka aplikasi kembali \\
\hline 8 & Kamera terdeteksi oleh sistem \\
\hline 9 & Guru membantu siswa mengarahkan kamera pada marker \\
\hline 10 & Sistem mendeteksi marker \\
\hline 11 & $\begin{array}{l}\text { Apabila marker tidak terdeteksi, arahkan kembali kamera ke arah } \\
\text { marker }\end{array}$ \\
\hline 12 & Sistem menampilkan objek animasi hewan \\
\hline 13 & Selesai \\
\hline
\end{tabular}

\subsection{Antar Muka menu utama}

Antar muka menu utama merupakan tampilan awal pada saat aplikasi di jalankan. Terdapat menu mulai di dalamnya. Tampilan menu utama dapat dilihat pada gambar 4.12

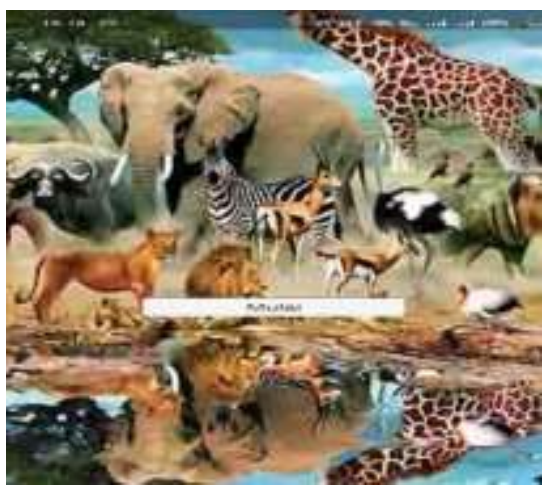

Gambar 4. 5 Antar Muka Menu Utama

Gambar 4.5 merupakan tampilan dari menu utama pada aplikasi pengenalan hewan dengan teknologi realitas augmentasi. Terdapat satu tombol di dalamnya yaitu tombol mulai.

\subsection{Antar muka dalam aplikasi}

Antar muka dalam aplikasi merupakan tampilan yang akan di tampilkan ketika pengguna menekan tombol mulai pada tampilan menu utama. Tampilan awal aplikasi akan mengaktifkan kamera yang akan digunakan untuk mendeteksi marker yang akan di gunakan. Berikut adalah beberapa hasil animasi yang dapat terender oleh aplikasi :
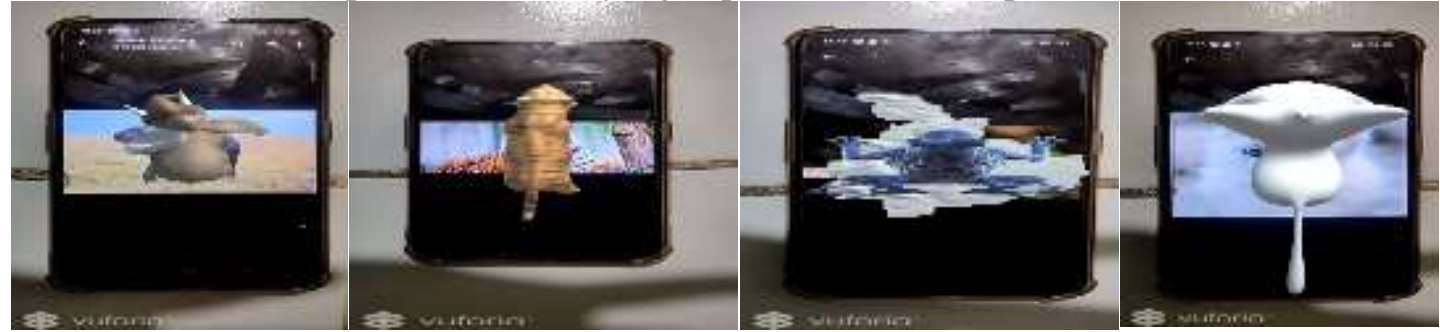

Gambar 4. 6 Hasil marker yang terdeksi oleh kamera sehingga memunculkan animasi

\section{Kesimpulan (Conclusion)}

Pada pembahasan yang telah diuraikan pada bab-bab sebelumnya dalam penulisan ini dapat disimpulkan tentang perancangan sistem aplikasi pengenalan hewan di PAUD Tunas Harapan Bangsa ini .Yang pertama sistem aplikasi pengenalan hewan dapat membantu para guru dalam mengembangkan metode belajar. Yang kedua, kegunaan aplikasi dapat mendukung guru PAUD Tunas Harapan Bangsa dalam menjalakan kegiatan belajar mengajar.Yang ketiga, kenambahkan metode baru terhadap sistem belajar mengajar yang berada di PAUD Tunas Harapan Bangsa. 
https://jurnal.amikwidyaloka.ac.id/index.php/awl

jurnal@amikwidyaloka.ac.id / editor.jurnalwidya@gmail.com

\section{Referensi (Reference)}

[1] Ariftama, B. (2015). Panduan Mudah Membuat Augmented Reality (Seno (ed.)). Penerbit ANDI.

[2] Hanggoro, A. C., Kridalukmana, R., \& Martono, K. T. (2015). Pembuatan Aplikasi Permainan "Jakarta Bersih" Berbasis Unity. Jurnal Teknologi Dan Sistem Komputer, 3(4), 503. https://doi.org/10.14710/jtsiskom.3.4.2015.503-511

[3] Haryani, P., \& Triyono, J. (2017). Augmented Reality (Ar) Sebagai Teknologi Interaktif Dalam Pengenalan Benda Cagar Budaya Kepada Masyarakat. Simetris : Jurnal Teknik Mesin, Elektro Dan Ilmu Komputer, 8(2), 807. https://doi.org/10.24176/simet.v8i2.1614

[4] Mantasia, M., \& Jaya, H. (2016). Pengembangan Teknologi Augmented Reality Sebagai Penguatan Dan Penunjang Metode Pembelajaran Di Smk Untuk Implementasi Kurikulum 2013. Jurnal Pendidikan Vokasi, 6(3), 281. https://doi.org/10.21831/jpv.v5i3.10522

[5] Mulyadi, M. (2013). Riset Desain Dalam Metodologi Penelitian. Jurnal Studi Komunikasi Dan Media, 16(1), 71. https://doi.org/10.31445/jskm.2012.160106

[6] Muntahanah, M., Toyib, R., \& Ansyori, M. (2017). Penerapan Teknologi Augmented Reality Pada Katalog Rumah Berbasis Android (Studi Kasus Pt. Jashando Han Saputra). Pseudocode, 4(1), 81-89. https://doi.org/10.33369/pseudocode.4.1.81-89

[7] Nugroho, A., \& Pramono, B. A. (2017). Aplikasi Mobile Augmented Reality Berbasis Vuforia Dan Unity Pada Pengenalan Objek 3D Dengan Studi Kasus Gedung M Universitas $\begin{array}{llll}\text { Semarang. Jurnal Transformatika, } & \text { 14(2), }\end{array}$ https://doi.org/10.26623/transformatika.v14i2.442

[8] Rusnandi, E., Sujadi, H., Fibriyany, E., \& Fauzyah, N. (2016). Implementasi Augmented Reality ( AR ) pada Pengembangan Media Pembelajaran Pemodelan Bangun Ruang 3D untuk Siswa Sekolah Dasar. Infotech Journal, 24-31.

[9] Yuliono, T., Sarwanto, S., \& Rintayati, P. (2018). Keefektifan Media Pemelajaran Augmented Reality terhadap Penguasaan Konsep Sistem Pencernaan Manusia. Jurnal Pendidikan Dasar, 3(3), 65-84

[10] Adi Mardian, Thomas Budiman, Rachmawaty Haroen; Verdi Yasin (2021), Perancangan Aplikasi Pemantauan Kinerja Karyawan Berbasis Android di PT. Salestrade Corp. Indonesia, "Jurnal Manajemen Informatika Jayakarta", E-ISSN : 2797-0930 (Online), P-ISSN : 27465985 (Print), Volume 1, Nomor 3,Juli 2021, halaman 169-185, DOI:

10.52362/jmijayakarta.v1i3.481, URL Publikasi: http://iournal.stmikjayakarta.ac.id/index.php/JMIJayakarta/article/view/481

[11] Nandang Mulyana, Agus Sulistyanto, Verdi Yasin (2021), Perancangan sistem informasi pengelolaan aset it berbasis web pada pt mandiri axa general insurance, "Jurnal Manajemen Informatika Jayakarta”, E-ISSN : 2797-0930 (Online), P-ISSN : 2746-5985 (Print), Volume 1, Nomor 3, Juli 2021, halaman 243-257, DOI: 10.52362/imijayakarta.v1i3.498, URL Publikasi: http://journal.stmikjayakarta.ac.id/index.php/JMIJayakarta/article/view/498

[12] Maulia Usnaini, Verdi Yasin, Anton Zulkarnain Sianipar (2021), Perancangan sistem informasi inventarisasi aset berbasis web menggunakan metode waterfall, "Jurnal Manajemen Informatika Jayakarta", E-ISSN : 2797-0930 (Online), P-ISSN : 2746-5985 (Print) Volume 1, Nomor 1,Februari 2021, halaman 36-55, DOI: 10.52362/jmijayakarta.v1i1.415, URL Publikasi: http://journal.stmikjayakarta.ac.id/index.php/JMIJayakarta/article/view/415

[13] Putri Setiani, Ifan Junaedi, Anton Zulkarnain Sianipar, Verdi Yasin (2021), Perancangan sistem informasi pelayanan penduduk berbasis website di rw 010 Kelurahan Keagungan Kecamatan Tamansari - Jakarta Barat. "Jurnal Manajemen Informatika Jayakarta", E-ISSN : 2797-0930 (Online), P-ISSN : 2746-5985 (Print) Volume 1, Nomor 1,Februari 2021, halaman 20-35, DOI: 10.52362/imijayakarta.v1i1.414, URL Publikasi: http://journal.stmikjayakarta.ac.id/index.php/JMIJayakarta/article/view/414 
https://jurnal.amikwidyaloka.ac.id/index.php/awl jurnal@amikwidyaloka.ac.id / editor.jurnalwidya@gmail.com

[14] Benni Triyono, Sri Purwanti, Verdi Yasin (2017) "Rekayasa Perangkat Lunak Sistem Informasi Pengiriman Dan Penerimaan Surat Atau Paket Berbasis Web", Journal of Information System, Applied, Management, Accounting and Research, e-ISSN: 2598-8719. p-ISSN: 2598-8700.Vol.1 No.1 (30 Desember 2017) p46-53 http://journal.stmikjayakarta.ac.id/index.php/iisamar/article/view/12

[15] Verdi Yasin, Muhammad Zarlis, Mahyuddin K.M. Nasution (2018) "Filsafat Logika Dan Ontologi Ilmu Komputer", Journal of Information System, Applied, Management, Accounting and Research, e-ISSN: 2598-8719. p-ISSN: 2598-8700.Vol.2 No.2 (19 Juni 2018) p68-75 http://journal.stmikjayakarta.ac.id/index.php/iisamar/article/view/39

[16] Julinda Maya Paramudita, Verdi Yasin (2019) "Perancangan Aplikasi Sistem Penyewaan Alat Berat “, Journal of Information System, Applied, Management, Accounting and Research, e-ISSN: 2598-8719. p-ISSN: 2598-8700.Vol.3 No.1 (20 Februari 2019) p23-29 http://journal.stmikjayakarta.ac.id/index.php/jisamar/article/view/73

[17] Muryan Awaludin, Verdi Yasin (2020) "Application Of Oriented Fast And Rotated Brief (Orb) And Bruteforce Hamming In Library Opencv For Classification Of Plants", Journal of Information System, Applied, Management, Accounting and Research, e-ISSN: 2598-8719. p-ISSN: 25988700.Vol.4 No.3 (14 Agustus 2020) p51-59 http://iournal.stmikjayakarta.ac.id/index.php/iisamar/article/view/247

[18] Ifan Junaedi, Dimas Abdillah, Verdi Yasin (2020) "Analisis Perancangan Dan Pembangunan Aplikasi Business Intelligence Penerimaan Negara Bukan Pajak Kementerian Keuangan RI”, Journal of Information System, Applied, Management, Accounting and Research, e-ISSN: 2598-8719. pISSN: 2598-8700.Vol.4 No.3 (14 Agustus 2020) p88-101 http://iournal.stmikjayakarta.ac.id/index.php/iisamar/article/view/249

[19] Verdi Yasin (2012) 'Rekayasa Perangkat Lunak Berorientasi Objek”, Penerbit: Mitra Wacana Media, Jakarta-Indonesia.

[20] Anis Rohmadi, Verdi Yasin (2020) "Desain Dan Penerapan Website Tata Kelola Percetakan Pada CV Apicdesign Kreasindo Jakarta Dengan Metode Prototyping", Journal of Information System, Informatics and Computing. E-ISSN: 2597-3673 (Online), P-ISSN: 2579-5201 (Print) Vol. 4 No.1, June 22, 2020. Pp.70-85 http://journal.stmikjayakarta.ac.id/index.php/jisicom/article/view/210

[21] Septian Cahyadi, Verdi Yasin, Mohammad Narji, Anton Zulkarnain Sianipar (2020) "Perancangan Sistem Informasi Pengiriman Dan Penerimaan Soal Ujian Berbasis Web ( Studi Kasus: Fakultas Komputer Universitas Bung Karno)", Journal of Information System, Informatics and Computing._E-ISSN: 2597-3673 (Online), P-ISSN: 2579-5201 (Print) Vol. 4 No.1, June 22, 2020. Pp.1-16 http://journal.stmikjavakarta.ac.id/index.php/iisicom/article/view/199

[22] Ifan Junaedi, Ndaru Nuswantari, Verdi Yasin (2019) "Perancangan Dan Implementasi Algoritma C4.5 Untuk Data Mining Analisis Tingkat Risiko Kematian Neonatum Pada Bayi", Journal of Information System, Informatics and Computing. E-ISSN: 2597-3673 (Online), P-ISSN: 25795201 (Print) Vol. 3 No.1, February 13, 2019. Pp.29-44. http://journal.stmikjayakarta.ac.id/index.php/jisicom/article/view/203

[23] Verdi Yasin, Anindra Ramdhan Nugraha, Muhammad Zarlis, Ifan Junaedi (2018) "Smart System Of Fast Internet Access Development Using Backbone Network Method", Journal of Information System, Informatics and Computing. E-ISSN: 2597-3673 (Online), P-ISSN: 2579-5201 (Print) Vol. 2 No. 2, December 31, 2018. Pp.26-34. http://journal.stmikjayakarta.ac.id/index.php/jisicom/article/view/198

[24] Ito Riris Immasari, Verdi Yasin (2019) "Penggunaan Metode Analytic Hierarchy Process Untuk Menganalisis Faktor-Faktor Yang Mempengaruhi Pemilihan Calon Legislatif Di Dprd Ii Kota Tangerang", Journal of Information System, Informatics and Computing. E-ISSN: 2597-3673 (Online), P-ISSN: 2579-5201 (Print) Vol. 3 No. 2, December 10, 2019. Pp.53-58. http://journal.stmikjayakarta.ac.id/index.php/jisicom/article/view/139

[25] Verdi Yasin, Muhammad Zarlis, Tulus, Erna Budhiarti Nababan, Poltak Sihombing (2019) "Rancangan Miniatur Otomatisasi Bel Listrik Pada Gerbang Pintu Menggunakan Microkontroler Atmega8535", Journal of Information System, Informatics and Computing. E-ISSN: 2597-3673 (Online), P-ISSN: 2579-5201 (Print) Vol. 3 No. 1, February 13, 2019. Pp.13-20 http://journal.stmikjayakarta.ac.id/index.php/jisicom/article/view/68 
Volume 2, Nomor 2,Oktober 2021: halaman 102-114

https://jurnal.amikwidyaloka.ac.id/index.php/awl

jurnal@amikwidyaloka.ac.id / editor.jurnalwidya@gmail.com

[26] Anggeri S. Nurjaman, Verdi Yasin (2020) "Konsep Desain Aplikasi Sistem Manajemen Kepegawaian Berbasis Web Pada PT. Bintang Komunikasi Utama ”, Journal of Information System, Informatics and Computing. E-ISSN: 2597-3673 (Online), P-ISSN: 2579-5201 (Print) Vol. 4 No. 2, December 28, 2020. Pp.143-174 http://journal.stmikjayakarta.ac.id/index.php/jisicom/article/view/363

[27] Verdi Yasin, Azhar Ahmad Riza, Rumadi Hartawan (2017) "Pengembangan Aplikasi Pemulihan Layanan Bencana Sistem Informasi Peneriman Negara Bukan Pajak Online Di Lingkungan Kementerian Keuangan Republik Indonesia", Journal of Information System, Informatics and Computing. E-ISSN: 2597-3673 (Online), P-ISSN: 2579-5201 (Print) Vol. 1 No. 1, September 20, 2017. Pp.33-56. http://journal.stmikjayakarta.ac.id/index.php/jisicom/article/view/4 